University of Rhode Island

DigitalCommons@URI

The Rhode Island Current Conditions Index

Economics

$11-2011$

\title{
Rhode Island Current Conditions Index - November 2011
}

Leonard Lardaro

University of Rhode Island, lardaro@uri.edu

Follow this and additional works at: https://digitalcommons.uri.edu/ricci

Part of the Econometrics Commons

Terms of Use

All rights reserved under copyright.

\section{Recommended Citation}

Lardaro, Leonard, "Rhode Island Current Conditions Index - November 2011" (2011). The Rhode Island Current Conditions Index. Paper 28.

https://digitalcommons.uri.edu/ricci/28

This Article is brought to you for free and open access by the Economics at DigitalCommons@URI. It has been accepted for inclusion in The Rhode Island Current Conditions Index by an authorized administrator of DigitalCommons@URI.For more information, please contact digitalcommons-group@uri.edu. 


\title{
CURRENT CONDITIONS INDEX LEONARD LARDARO, URI
}

\author{
Available Online: http:/ / www.llardaro.com/ current.htm (NEW URL) \\ Blog: http:/ / rieconomy.blogspot.com
}

VOL XVI I I

NUMBER 12

NOV 2011
Rhode Island's economy finally showed a spark of life in November, as it was able to break out of the neutral range it had been stuck in since May. The Current Conditions Index rose to 67 in November, its highest value since February, as eight of twelve indicators improved.

While this month's reading may be a signal that Rhode Island's economy has finally moved to a sustainable higher level of economic activity, I believe it is still too early to make that call. Why? As I have stated numerous times over the years, in tracking the overall performance of Rhode Island's economy, there are always groups of positive and negative forces interacting. Whichever of these dominates ultimately determines the overal direction our state's economy takes. Suffice it to say that there was a great deal of such interaction in November.

Even though the November $\mathrm{CCl}$ showed a substantial improvement, it still lagged behind its value of 75 last November. The Current Conditions Index has now failed to match or exceed its year-earlier value for nine consecutive months. Perhaps more importantly, a critical indicator of Rhode Island's performance, Retail Sales, did manage to improve again on a yearly basis $(+1.8 \%)$ while declining for a third consecutive time in terms of

\begin{tabular}{|l|r|r|}
\hline \multicolumn{3}{|c|}{ CCI Indicators - \% Change } \\
\hline Government Employment & -2.3 & \\
\hline US Consumer Sentiment & -10.6 & \\
\hline Single-Unit Permits & 3.0 & Y \\
\hline Retail Sales & 1.8 & Y \\
\hline Employment Services J obs & 0.3 & Y \\
\hline Priv. Serv-Prod Employment & 0.2 & Y \\
\hline Total Manufacturing Hours & 0.6 & Y \\
\hline Manufacturing Wage & 17.0 & Y \\
\hline Labor Force & -2.5 & \\
\hline Benefit Exhaustions & -27.3 & Y \\
\hline New Claims & 0.2 & \\
\hline Unemployment Rate (change) & -1.0 & Y \\
\hline \multicolumn{2}{|c|}{ Y= Improved Value } \\
\hline
\end{tabular}

monthly change. This raises the obvious question of the sustainability of late- 2011 levels of Retail Sales as we move into 2012. Yet Retail Sales was able to register these recent annual gains in spite of declining US Consumer Sentiment. Furthermore, on a monthly basis, US Consumer Sentiment has now improved for three consecutive months. It will be interesting to see how this interaction plays out, especially since personal income for Rhode Island actually declined in Q3.

One other indicator, the Labor Force, has continued to perform very badly on a yearly basis, as it has now failed to improve every month since February. But it too has begun to improve on a monthly basis, and along with this monthly improvement has come higher levels of resident employment, a very positive sign, and a falling Unemployment Rate.

Two indicators that failed to improve in October showed improvement in November. The first of these is Single-Unit Permits, which reflects new home construction, and is perhaps the most volatile of the $\mathrm{CCl}$ indicators. Based on the volatility of this indicator, this month's improvement cannot be viewed a signal that new home construction has bottomed. The other is Total Manufacturing Hours, a mainstay of this recovery, which barely increased $(0.6 \%)$, but did reverse last month's decline.

Of the remaining indicators, Employment Service Jobs, a leading labor market indicator that includes "temps," rose by 0.3 percent, only its second improvement since February. This indicator may well have bottomed. Private Service-Producing Employment continued to grow, albeit slowly $(+0.2 \%)$. Not surprisingly, Government Employment fell once again in November $(-2.3 \%)$, while New Claims, a leading labor market indicator that indicates layoffs, rose by 0.2 percent, its fifth consecutive failure to improve. Are layoffs trending higher?

The Manufacturing Wage surged by 17 percent in November to $\$ 17.38$, if anyone actually believes this, following several doubledigit increases in prior months. Finally, Benefit Exhaustions continued its trend of improvements, falling by 27.3 percent.

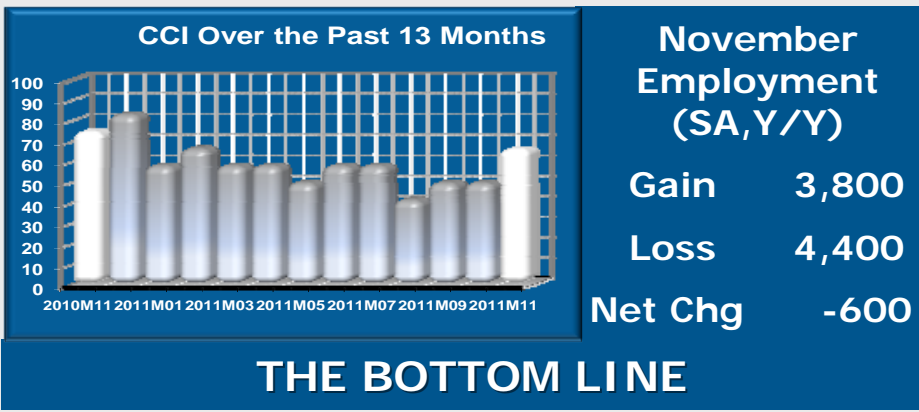

The pressing question for now is whether Rhode Island's economy has broken out of the neutral range it has been stuck in for many months. Several elements within the November data that suggest that this might be the case while others imply that sustained improvement might not materialize. All of this is complicated by likelihood of revisions to the existing labor market data, as data for the final months of the year are those most likely to be changed when rebenchmarking occurs. We'll just have to wait and see.

\begin{tabular}{|c|c|c|c|c|c|c|c|c|c|c|c|c|c|}
\hline & & Jan & Feb & Mar & Apr & May & J un & J ul & Aug & Sep & Oct & Nov & Dec \\
\cline { 2 - 32 } & 2010 & 42 & 58 & 67 & 67 & 75 & 75 & 83 & 83 & 67 & 67 & 75 & 83 \\
\cline { 2 - 15 } & 2011 & 67 & 67 & 58 & 58 & $50 \downarrow$ & 58 & $58 \downarrow$ & 42 & 50 & 50 & 67 & \\
\hline
\end{tabular}

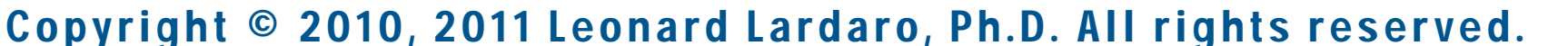

